\begin{tabular}{ll}
\hline & $\begin{array}{l}\text { Kastamonu Eğitim Dergisi } \\
\text { Kastamonu Education Journal }\end{array}$ \\
$\begin{array}{l}\text { Eylül } 2019 \text { Cilt:27 Sayı:5 } \\
\text { kefdergi.kastamonu.edu.tr }\end{array}$ & $\begin{array}{r}\text { Başuru Tarihi/Received: } 24.07 .2018 \\
\text { Kabul Tarihi/Accepted: } 07.02 .2019 \\
\text { Dol: } 10.24106 / \text { kefdergi.3238 }\end{array}$ \\
\hline
\end{tabular}

\title{
4. Sınıf Öğrencilerinin Fen Bilimleri Dersinde Karşılaştıkları Rutin Olmayan Problemleri Çözme Düzeyi
}

\section{Levels of Grade 4 Students to Solve Non-Routine Problems in Science Course}

\section{Özet}

\author{
Zeki APAYDIN ${ }^{1}$ Mehmet Ali KANDEMiR ${ }^{2}$
}

Bu çalışmanın amacı, 4. sınıf öğrencilerinin rutin olmayan problemleri çözme düzeylerini ve cinsiyet ile problem çözme becerisi arasındaki ilişkiyi belirlemektir. Bu çalışma, Marmara Bölgesi'nde yer alan bir ilin; bir ilçesinde 4. sınıfa devam eden 140 öğrencinin katılımı ile gerçekleştirilmiştir. Bu çalışma, nicel araştrrma yöntemlerinden biri olan tarama çalışmasına göre düzenlenmiştir. Veriler, öğrencilerin 5 adet probleme vermiş olduğu yanıtlardan elde edilmiştir. Elde edilen veriler yüzde, frekans ve kay kare testinden yararlanılarak analiz edilmiştir. Bu çalışma sonucunda öğrencilerin problem çözme düzeylerinin istenilen seviye olmadığı; problem çözme becerisi ile cinsiyet arasında ilişki incelendiğinde kızlar lehine anlamlı bir farklılı̆ı̆n olduğu sonucuna ulaşılmıştır.

Anahtar Kelimeler: problem çözme, rutin olmayan problemler

\section{Abstract}

The purpose of this study is to determine the level of solving non-routine problems of 4 th grade students and the relationship between gender and problem-solving skills.This study was carried out with the participation of 140 students attending 4th grade in a district of a province in Marmara Region. This study was organized according to the screening study, which is one of the quantitative research methods. Data were obtained from the students' answers given to 5 problems. The obtained data were analyzed using percentage, frequency and chi-squared test. As a result of this study, it was concluded that the level of problem solving of the students was not the desired level and that there was a meaningful difference between the problem solving skill and the gender in favor of the girls.

Keywords: problem solving, non-routine problems 


\section{Extended Abstract}

Introduction: One of the characteristics that individuals in the 21st century should have is problem solving skills. One of the most important reasons for this is that the individual is likely to face many complex problems with the rapid development of science and technology in the future. Individuals who can not solve these problems can be unhappy. For this reason, individuals need to have the ability to find solutions to the problems they face in order to be happy.

The purpose of this study is to determine whether there is a significant difference between the ability of 4th grade students to solve non-routine problems prepared within the scope of science lesson and the problem-solving skills by sex.

Method: This study was carried out with the participation of 140 students attending 4th grade in a district of a province in Marmara Region. Students were selected by appropriate sampling method. This study was designed according to the screening pattern, which is one of the quantitative research designs. The data of the study were obtained by applying to the students 5 non-routine problems with validity and validity. The data obtained in the study were evaluated using percentage, frequency and chi-square test.

Results: 1 . The first research question, " 4 . what is the level of classroom students' solving non-routine problems that are prepared within the science class? "The findings of the five problems that students have answered in the context of this question are as follows:

Findings of the first problem: When we examine Table 2, it is observed that 20 (14.28\%) students, of which 9 are girls, answered correctly and $120(85.72 \%)$ students did not answer the problem.

Findings of the second problem: When we examine Table 3 , it is seen that $11(7.86 \%)$ students answered correctly, 2 (1.43\%) students answered partially, and 127 (90.71\%) students did not answer the second question.

Findings of the third problem: When we examine Table 4, it is seen that 13 (\% 9.29) students gave correct answers to the third question, 64 (45.71\%) students answered partially, and 127 (45\%) students did not answer the problem.

Findings of the fourth problem: When we look at Table 5, it is seen that 22 (15.71\%) students answered correct answers to the fourth question, 69 (49.29\%) students answered partially, and 49 (35\%) students did not answer the problem.

Findings for fifth probing: When we look at Table 6, it is seen that 7 (5\%) students gave correct answers to the fourth question, $72(51.43 \%)$ students answered partially and 61 (43.57\%) students did not answer the problem.

Conclusion, discussion and suggestions: When we examined the research results in general, it was seen that the students had difficulty in transferring the information they learned to daily life and that the problem-solving skills differed significantly from the gender variable. Based on these results, teachers can be given training to enhance their competence in developing problem-solving skills. The number of problem solving activities for everyday life can be increased in textbooks. There may be more room for daily life problems during the exams. 


\section{Giriş}

Yirmi birinci yüzyılda bilgiyi üretip kullanabilen, eleştirel bir bakış açısına ve girişimci bir ruha sahip, problemlerle karşılaştı̆ında kararlııkla çözüm önerileri ileri sürebilen, empati kurabilen, topluma ve kültüre katkıda bulunabilen bireylere gereksinim duyulmaktadır (MEB, 2018). İlgili özelliklerin ve becerilerin ortaya çıkmasının nedenleri arasında, bilim ve teknolojinin hızlı değişim göstermesi ve buna bağlı olarak insanların gereksinimlerinin değişmesi, öğrenme teorilerinde meydana gelen değişikliklerin bireylerden beklenen rolleri etkilemesi şeklinde verilebilecek faktörler sayılabilirler. Belirtilenlerden hareketle, günümüzde bireylerde bulunması gereken öncelikli özelliklerden birinin problem çözme becerileri olduğu ileri sürülebilir. Problem çözme becerilerinin önemi; bireyin gelecekte bilim ve teknolojinin hızlı gelişmesine bağıı olarak, karmaşık birçok sorunla karşı karşıya kalma olasılığının yüksek olmasından gelmektedir. Karşılaştkları problemleri çözme becerisi sergileyemeyen bireyler mutsuz bir hayat sürebilirler. Problem çözme becerilerinin bireylerin hayattan zevk alabilme ve mutlu olabilmeleriyle ilişkili olduğu açıktı (Csapo \& Funke, 2017; Koç, 2014; MEB, 2017; Saracaloğlu, Serin ve Bozkurt, 2001). Öyleyse bireylerin problem çözme becerisinin gelişimine katkıda bulunabilmek için; problemlere çözüm üretmeyi mümkün kılan düşünce süreçleriyle karşılaştrılmaları oldukça önemlidir. Bunun yanında problem çözme becerisini geliştirmek sadece karşılaşılan problemleri çözmekle kalmamalı, ilgili konu başıkları problem senaryoları halinde verilmelidir. Böylece problem çözme, bireylerin yaşam tarzı haline getirilebilecektir (Altun, 2008; Dostal, 2015).

Alan yazın incelendiğinde, karşımıza problem ve problem çözme kavramlarının birçok tanımı çıkmaktadır. Bu tanımlardan bazıları şunlardır: Problem, bireyin karşılaştı̆ı bir olayı o andaki bilgi birikimiyle açıklayamaması durumuna işaret eder (Çepni, 2014). Problem çözme, bir zorluktan çıkış yolu bulma sürecidir (Rohmah \& Sutiarso, 2018). Problem, kişinin ulaşmak istediği amaçların, önündeki engel ya da engellerdir. Problem çözme ise, amaçların önündeki engelleri aşma sürecidir. Benzer biçimde birey bir olgusal durumla karşı karşıya kaldığında, çözüm önerileri getiremiyorsa, yine bir problemin varlığından bahsedilebilir. Bu durumda problem çözme, problem olarak algılanan durumlarda yapılması gerekenleri bilmek olarak tanımlanabilir. Problem çözme becerisi, problemle karşılaşıldığında onun doğasını kavrama ve anlama, uygun çözüm yolu bulma, bu yolu uygulama ve sonuçları yorumlama yeteneklerini kapsar (Altun, 2008; Bingham, 2004).

Problemler rutin ve rutin olmayan problemler şeklinde iki başlık altında incelenebilirler (Işık ve Kar, 2011). Rutin problemler dört işlem becerisi ile çözülebilen problemlerdir. Bu tip problemler, bireylerin günlük hayattaki işlem becerilerine, problem hikâyesini matematiksel olarak ifade edebilmelerine, düşüncelerini şekillerle betimleyebilmelerine ve problem çözmenin gerektirdiği diğer becerileri kazanmalarına katkıda bulunur. Rutin problemler, bilinen bir kural ya da formül kullanılarak çözülebilir. Rutin olmayan problemler ise, rutin problemlerin aksine ilk bakışta görülebilecek basit çözümlere sahip değillerdir; analiz edebilme ve özgün stratejiler geliştirme biçiminde ifade edilebilecek üst düzey düşünme becerilerini kapsayan ve gelişmesine katkıda bulunan zorlayıcı problemlerdir (Altun, 2008; Boonen, Reed, Schoonenboom \& Jolles, 2016; Celebioğlu, Yazgan \& Ezentaş, 2010; Inoue, 2005; Van Garderen \& Montague, 2003). Problem çözme becerilerinin öğrencilere kazandırılmasında, kuşkusuz ki öğretmenlerin problem çözme becerilerinin etkisi oldukça fazladır. Bu bağlamda problem çözmenin kurallarından değil; sistematiğinden söz edilebilir. Bu sistematiği öğretmek de öğretmenlerden beklenen görevlerindendir (Bağçeci ve Kinay, 2013; Altun, 2008). Benzer şekilde öğrencilerin problem çözme becerilerini kazanması üzerinde; öğretmenlerin bu becerileri etkili bir şekilde öğretmeye yönelik pedagojik stratejilerle donanımlı olmasının etkisi büyüktür. Öğretmenlerin problem çözme konusundaki yeterliği özellikle ilkokul düzeyinde oldukça önemlidir. İlkokul öğretmenlerinin oyun çağındaki öğrencilerin gelecekte karşılaşacakları karmaşık problemlerin çözümüne yönelik, problem çözme becerilerini geliştirme sorumluluğu vardır (Makata, Cobern, Grunert, Mutambuki \& Akom, 2014; Nasriah, 2017).

Bir problem çözme sürecinde öğretmenlerin görev ve sorumlulukları aşağıdaki gibi ifade edilebilir:

- Problem senaryoları gerçek yaşamdan belirlenmelidir.

- Öğretmen çözülecek problemleri öğrencilerin ilgilerine göre belirlemelidir.

- Problemi belirlerken öğrencilerin düşüncelerine başvurmalıdır.

- Öğrencilere benzer problem çözme çalışmaları yaptırmalıdır.

- Problemler belirlenirken öğrenci düzeyleri dikkate alınmalıdır.

- Problemin önemi öğrenciye anlatımalıdır.

- Öğrencilerin gerekli araç ve gereç gereksinimi karşılanmalıdır.

- Öğrencilerin, ulaştıkları çözüm yollarını başka problemlerde kullanılması da sağlanmalıdır.

- Problem çözme sürecinin değerlendirilmesi sağlanmalıdır (Aykaç, 2005; Çepni, 2014; Doğanay, 2012). 
Bütün problemlerin etkili bir biçimde çözülmesini sağlayacak tek bir yöntem yoktur. Çünkü problem çözme davranışı; bireyden bireye, problemden probleme, zamana ve duruma göre değişiklik gösterebilir (Bingham, 2004). Buna rağmen problem çözerken kullanılan bazı ortak basamaklar vardır. Bunlar: Problemin farkına varılması, problemi tanımlama, problemin çözümü olabilecek çözüm yollarını belirleme, veri toplama, verileri değerlendirme, genelleme ve sonuçlara ulaşma, çözümü uygulama ve değerlendirmedir (Açıkgöz, 2014). Bir diğer yazara göre ise süreç; problemi anlamak, problemin çözümü için plan yapmak, yapılan planı uygulamak ve çözümü kontrol etmek şeklindedir (Polya, 1997). Problem çözme becerisi, 2017 yılında yenilenen öğretim programlarında vurgulanmış ve çağımızın bütün bireylerinde olması gereken bir özellik olarak belirtilmiştir. Bu nedenle çalışmada ulaşılan bulguların, öğrencilerin yenilenen fen bilimleri öğretim programında (MEB, 2018) edindikleri kazanımları günlük yaşamda kullabilme düzeylerinin belirlenmesinde ve yeni öğretim programının uygulama boyutunun değerlendirilmesinde katkı sağlayacağı ifade edilebilir.

\section{Araştırma Amacı}

Bu çalışmanın amacı, 4. sınıf öğrencilerinin fen bilimleri dersinin maddeyi tanıyalım ünitesi kapsamında hazırlanan rutin olmayan problemleri çözme becerilerini ve cinsiyete göre problem çözme becerisi arasında anlamlı bir farklılı̆ın olup olmadığını belirlemektir.

\section{Araştırma Soruları}

1. 4. sınıf öğrencilerinin fen bilimleri dersinin maddeyi tanıyalım ünitesi kapsamında hazırlanan rutin olmayan problemleri çözme becerisi hangi düzeydedir?

2. Cinsiyete göre problem çözme düzeyleri arasındaki farklılık nasıldır?

\section{Yöntem}

\section{Araştırma Deseni}

Bu araştırma tarama desenine göre düzenlenmiştir. Tarama deseni bir durumu var olduğu şekliyle, duruma müdahale ve etkileme çabası içinde olmadan betimlemeyi amaçlamaktadır. Araştırmaya konu olan olay, birey ya da nesne kendi koşulları içinde ve olduğu gibi tanımlanmaya çalışııı. Tarama çalışmalarının önemli bir avantajı, oldukça çok bireyden oluşan örneklemden elde edilen birçok bilgiyi bize sunabilmesidir ( Büyüköztürk, Çakmak, Akgün, Demirel ve Karadeniz, 2016; Karasar, 1994).

\section{Çalışma Grubu}

Bu çalışma Marmara bölgesindeki bir ilin bir ilçesinde 4. sınıfa devam eden 140 öğrencinin katılımı ile gerçekleştirilmiştir. Çalışmada uygun örnekleme yöntemi kullanılmıştır. (Baydar, Gül ve Akçil, 2007; Büyüköztürk, Çakmak, Akgün, Demirel ve Karadeniz, 2016). Çalışmaya ulaşılması kolay, bilinen iki okuldaki 4. sınıf öğrencileri dahil edilmiştir.

\section{Veri Toplama Aracı}

Çalışmanın verileri, geçerliliği ve güvenirliliği sağlanmış olan “ Maddeyi tanıyalım” ünitesi kapsamında hazırlanmış 5 adet rutin olmayan problemin, öğrencilere uygulanmasıyla elde edilmiştir. Bu ünite kapsamında 12 tane problem maddesi hazırlanmış, uzman görüşleri doğrultusunda kapsam geçerliği göz önünde tutularak 5 madde seçilmiş ve bu maddeler üzerinde yine uzman görüşüleri doğrultusunda düzeltmeler yapılmıştır. Ayrıca, seçilen maddelerde anlaşılmayan yer olup olmadığını ve ortalama soru çözme süresini belirlemek için; araştrmaya katılan 13 öğrenciye pilot uygulama yapılmıştır. Bu uygulama sonucunda, soruların çözümü için öğrencilere 40 dakika verilmiş, öğrenciler tarafindan problemlerin anlaşıı olduğu belirtilmiştir. Geçerlilik ve güvenirlik için 5 adet alan uzmanının görüşlerinden yararlanılmıştır. Aynı zamanda problemler iki alan uzmanı tarafindan tekraren çözülmüş, alan uzmanlarının ulaştkları bulguların tutarlılık yüzdesi hesaplanmıştr. Bu hesaplama, (Tutarlılık yüzdesi= "Aynı cevaplanan problemler/Tüm problemler)*100") formülünden hareketle gerçekleştirilmiş ve sonuçta; iki alan uzmanın ulaştığı bulgular arasındaki güvenirlilik (tutarlılık) .90 çıkmıştır (Büyüköztürk, Çakmak, Akgün, Demirel ve Karadeniz, 2016; Çepni, 2010).

\section{Verilerin Analizi}

Araştırmada elde edilen veriler yüzde, frekans ve kay kare testi kullanılarak değerlendirilmiştir. Probleme doğru yanıt verene " 2 ", kISmen yanıt verene " 1 ", yanıt vermeyene "0" puan verilerek SPSS 22 paket programında verilerin frekans ve yüzde hesaplamaları yapılmıştır. Erkek ve kız öğrencilerden elde edilen verilerin normal dağılıma sahip olup olmadığını belirlemek için; grup büyüklüğü 50'den fazla olduğu durumlarda Kolmogorov Smirnov testi kullanılır. Bu testin sonucu $p=.00<.05$ olduğu için puanların normal dağılıma sahip olmadığı sonucu ortaya çıkmıştır. Bu nedenle 
erkek ve kız öğrenciler arasında anlamlı bir farklılı̆ın olup olmadığını belirlemek amacıyla kay kare testi kullanılmıştır (Büyüköztürk, 2016).

Tablo 1. Verilerin normallik test sonucu

\begin{tabular}{cc}
\hline Kolmogorov-Smirnov Testi & $\mathbf{P}$ \\
\hline Kızlar & 0.00 \\
Erkekler & 0.00 \\
\hline
\end{tabular}

\section{Bulgular}

Bu bölümde "Maddeyi Tanıyalım" ünitesi kapsamında hazırlanmış olan 5 adet rutin olmayan problemin öğrencilere uygulanmasıyla sağlanan, çözüme yönelik yazılı açıklamalar ortaya konulmuştur. Bulgular, 5 adet problem için ayrı ayrı betimlenmiştir. Ayrıca öğrenciler 1'den-140'a kadar Ö1Ö140 şeklinde kodlanmıştır.

Birinci araştırma sorusu, "4. sınıf öğrencilerinin fen bilimleri dersinin maddeyi tanıyalım ünitesi kapsamında hazırlanan rutin olmayan problemleri çözme becerisi hangi düzeydedir?" sorusudur. Bu sorunun yanıtına ilişkin problemlere ait bulgular aşağıda verilmiştir.

\section{Birinci Probleme iliş̧kin Bulgular}

Problem: Ahmet, süt satan babasına yardım etmektedir. Müşterilerden birisi 3 litre süt istemiştir. Fakat Ahmet'in elinde biri 5 litre diğeri 7 litrelik iki sürahi vardır. Ahmet, sizce 3 litreyi nasıl elde eder?

Tablo 2. Birinci probleme yönelik cevaplama dağııımı

\begin{tabular}{lcccccc}
\hline & Kız & \% & Erkek & $\%$ & $\begin{array}{c}\text { Toplam } \\
\text { (f) }\end{array}$ & $\begin{array}{c}\text { Toplam } \\
\%\end{array}$ \\
\hline Doğrucevap veren kişi sayısı & 9 & 12.67 & 11 & 15.94 & 20 & 14.28 \\
Kısmen doğru cevap veren & 0 & 0 & 0 & 0 & 0 & 0 \\
Cevaplamayan kişi sayısı & 62 & 87.33 & 58 & 84.06 & 120 & 85.72 \\
\hline
\end{tabular}

Tablo 2 incelendiğinde, birinci soruya 9'u kız öğrenci ve 11'i erkek öğrenci olmak üzere toplam 20 (\%14.28) öğrencinin doğru cevap verdiği; 120 (\%85.72) öğrencinin ise, problemi cevaplayamadığı belirlenmiştir.

1. Ahmet, süt satan babasına yardım etmektedir. Müşterilerden birisi 3 litre süt istemistir. Fakat Ahmet'in elinde biri 5 litre diğeri 7 litrelik iki sürahi var. Ahmet, sizce 3 litreyi nasil elde eder?

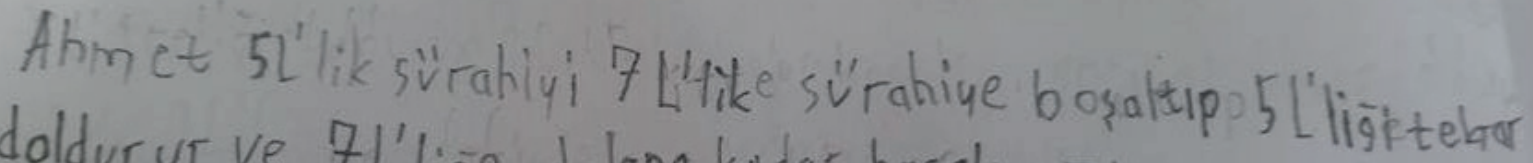

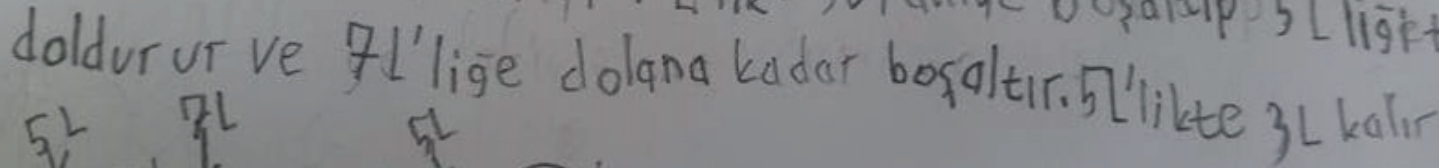
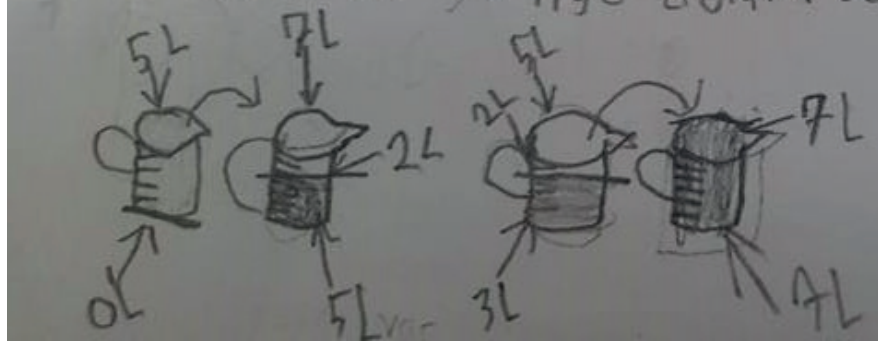

Şekil 1. Öğrencilere ait sırasıyla doğru ve yanlış cevaplar 


\section{ikinci Probleme ilişkin Bulgular}

Problem: Ahmet'in 20 paket cevizi vardır. Bu paketleri 5 kardeşine paylaştrrmak istemektedir. Bu paketlerden birincisi $1 \mathrm{~kg}$, ikincisi $2 \mathrm{~kg}, \ldots$, yirmincisi $20 \mathrm{~kg}$ gelmektedir. Bu paketler 5 kardeşe paket sayısı ile ceviz miktarı eşit olacak şekilde nasıl dağıtılır?

Tablo 3. İkinci probleme yönelik cevaplama dağılımı.

\begin{tabular}{lcccccc}
\hline & Kız & $\%$ & Erkek & $\%$ & $\begin{array}{c}\text { Toplam } \\
\text { (f) }\end{array}$ & $\begin{array}{c}\text { Toplam } \\
\%\end{array}$ \\
\hline Doğru cevap veren kişi saysı & 7 & 9.9 & 4 & 5.79 & 11 & 7.86 \\
Kısmen doğru cevap veren & 1 & 1,4 & 1 & 1.45 & 2 & 1.43 \\
Cevaplamayan kişi sayısı & 63 & 88.7 & 64 & 92.76 & 127 & 90.71 \\
\hline
\end{tabular}

Tablo 3 incelediğinde, ikinci soruya 7'si kız öğrenci ve 4'ü erkek öğrenci olmak üzere toplam 11 (\%7.86) öğrencinin doğru cevap verdiği, 2 (\%1.43) öğrencinin ise kısmen cevap verdiği, 127 (\%90.71) öğrencinin ise problemi cevaplayamadığı görülmektedir.

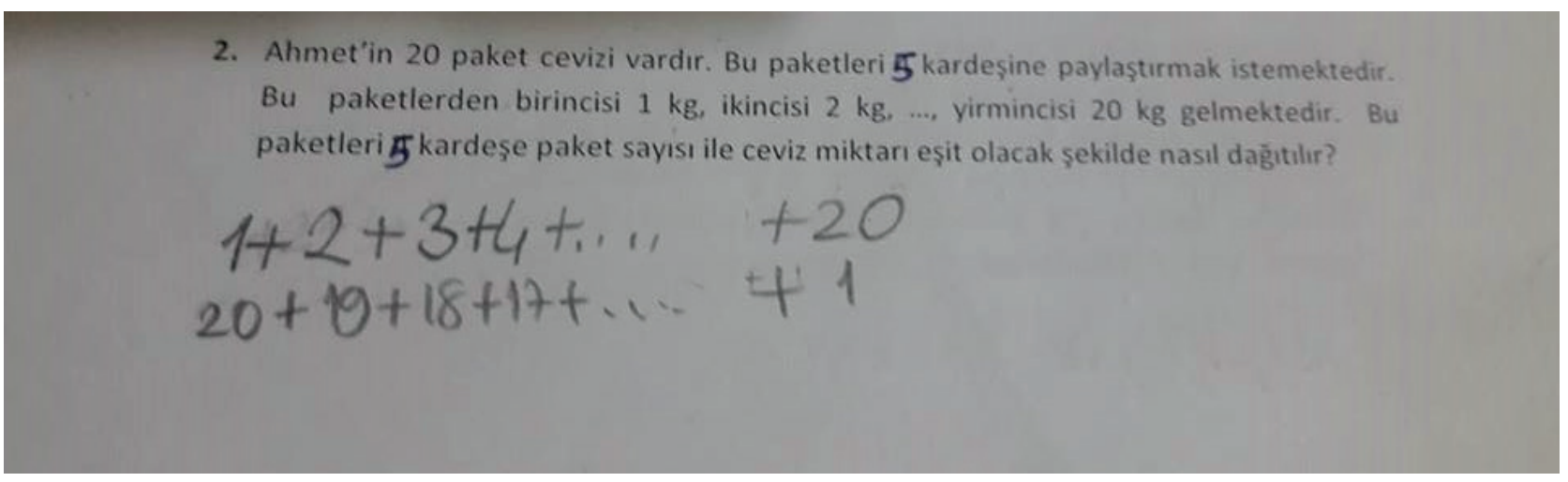

Şekil 2. Öğrencilere ait sırasıyla doğru ve kısmen doğru cevaplar

2. Ahmet' in 20 paket cevizi vardır. Bu paketleri 4 kardeşine paylaştırmak istemektedir. Bu paketlerden birincisi $1 \mathrm{~kg}$, ikincisi $2 \mathrm{~kg}$, ..., yirmincisi $20 \mathrm{~kg}$ gelmektedir. Bu paketleri 4 kardeşe paket sayısı ile ceviz miktarı eşit olacak şekilde nasıl dağıtılır?
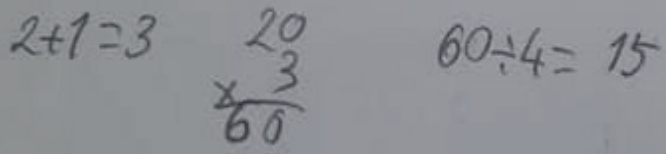

\section{Şekil 3. Öğrenciye ait yanlış cevap}

\section{Üçüncü Probleme Iliş̧in Bulgular}

Problem: Mehmet, şemsiyelere karşı ilgi duyuyordu. Özellikle rengârenk olanları gördüğünde dayanamıyor, onun gibi şemsiyesi olmasını istiyordu. Mehmet, bu ilgisi doğrultusunda kâğıt kullanarak şemsiye yaptr. Mehmet, bu duruma çok sevinmişti. Bir gün yağmur yağarken yapmış olduğu şemsiyeyi alıp, yağmurun altında yürüyüşe çıkt. Yağmurda yürürken bir süre sonra şemsiyenin suyu geçirdiğini ve delindiğini gördü ve çok üzüldü. Yeniden şemsiye yapmaya karar verdi. Şemsiye yaparken atacağı adımları düşünmeye başladı. Siz olsaydınız Mehmet'in yerine ne yapardınız? 
Tablo 4. Üçüncü probleme yönelik cevaplama dağılımı

\begin{tabular}{lcccccc}
\hline & Kız & $\%$ & Erkek & $\%$ & $\begin{array}{c}\text { Toplam } \\
\text { (f) }\end{array}$ & $\begin{array}{c}\text { Toplam } \\
\%\end{array}$ \\
\hline Doğru cevap veren kişi sayısı & 8 & 11.27 & 5 & 7.24 & 13 & 9.29 \\
Kısmen doğru cevap veren & 32 & 45,07 & 32 & 46.38 & 64 & 45.71 \\
Cevaplamayan kişi sayısı & 31 & 43.66 & 32 & 46.38 & 127 & 45 \\
\hline
\end{tabular}

Tablo 4'ü incelendiğinde, üçüncü soruya 8'i kız öğrenci ve 5'i erkek öğrenci olmak üzere toplam 13 (\%9.29) öğrencinin doğru cevap verdiği, 64 (\%45.71) öğrencinin ise kısmen cevap verdiği, 127 (\%45) öğrencinin ise problemi cevaplayamadığı görülmektedir.

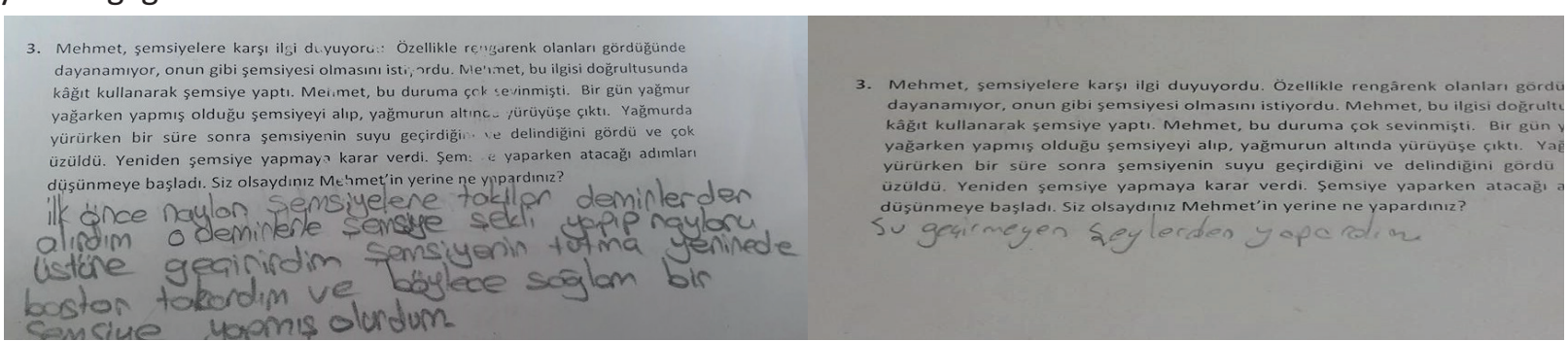

Şekil 4. Öğrencilere ait sırasıyla doğru ve kısmen doğru cevaplar

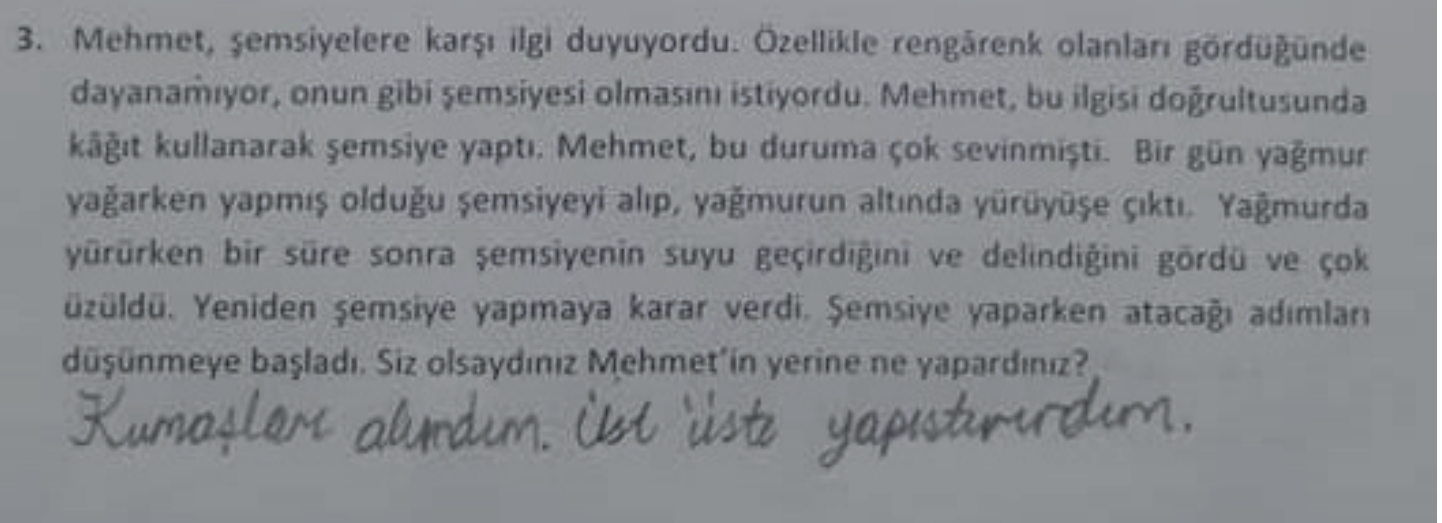

\section{Şekil 5. Öğrenciye ait yanlış cevap}

\section{Dördüncü Probleme Iliş̧in Bulgular}

Problem: Melek ve annesi bahçede oturuyordu. Annesi, Melek'ten dikiş kutusunu getirmesini istedi. Melek, kutuyu annesine götürürken bahçede ayağı takılıp düştü. iç̧inde iğnelerin, plastik düğmelerin, cam boncuklar ve makaraların olduğu kutuyu düşürdü. Melek, dikiş kutusundaki malzemeleri toprağın içerisinden nasıl ayırabilir?

Tablo 5. Dördüncü probleme yönelik cevaplanma dağılımı

\begin{tabular}{lcccccc}
\hline & Kız & \% & Erkek & \% & $\begin{array}{c}\text { Toplam } \\
\text { (f) }\end{array}$ & $\begin{array}{c}\text { Toplam } \\
\%\end{array}$ \\
\hline Doğru cevap veren kişi sayısı & 14 & 19.72 & 8 & 11.27 & 22 & 15.71 \\
Kısmen doğru cevap veren & 36 & 50.70 & 33 & 46.48 & 69 & 49.29 \\
Cevaplamayan kişi sayısı & 21 & 29.58 & 28 & 39.44 & 49 & 35 \\
\hline
\end{tabular}

Tablo 5 'i incelediğinde, dördüncü soruya 14 'ü kız öğrenci ve 8 'i erkek öğrenci olmak üzere toplam 22 (\%15.71) 
öğrencinin doğru cevap verdiği, 69 (\%49.29) öğrencinin ise kısmen cevap verdiği, 49 (\%35) öğrencinin ise problemi cevaplayamadığı görülmektedir.

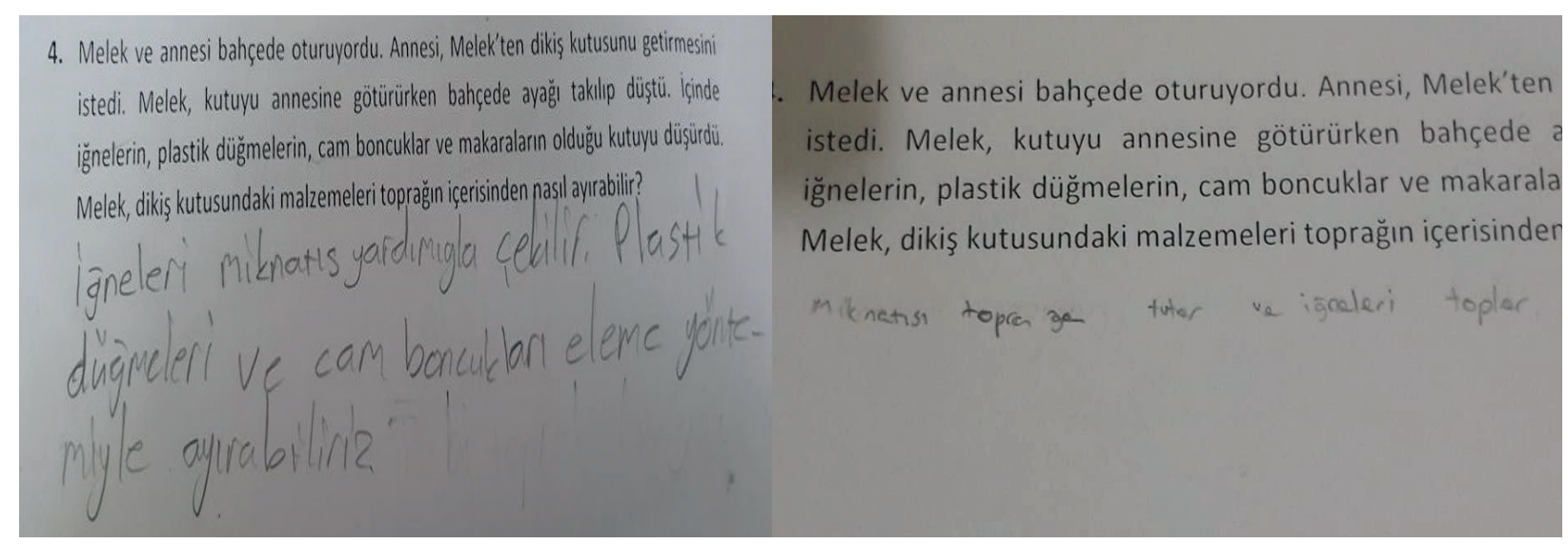

Şekil 6. Öğrencilere ait sırasıyla doğru ve kısmen doğru cevaplar

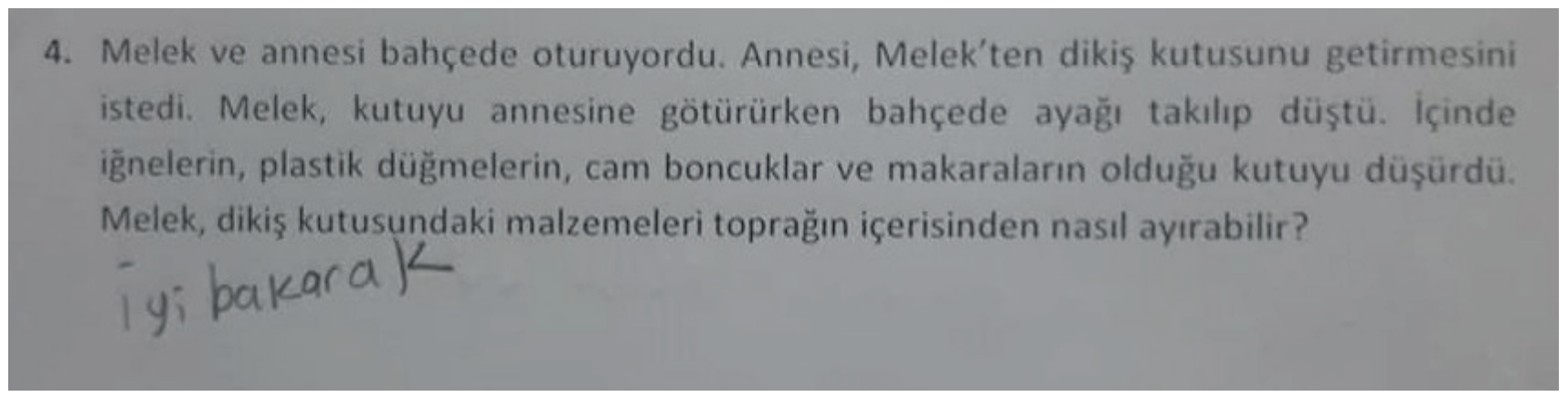

\section{Şekil 7. Öğrenciye ait yanlış cevap}

\section{Beşinci Probleme İlişkin Bulgular}

Problem: Ayşe, gazete okurken bir haber metni dikkatini çekmiştir, haber metni: "Doğal kaynaklar (Toprak, su, orman vb.) bilinçsizce tüketilmektedir. Bu süreç sonucunda birçok canlı hayatını kaybetmektedir. Doğal kaynaklar uzun sürede yenilendiği için dikkatli bir şekilde kullanılıp korunması gerekmektedir." şeklindedir. Ayşe metni okuduktan sonra bu duruma çok üzülmüştür. Ayşe, bu durumun çözümüne yönelik katkıda bulunacağını düşünmektedir. Sizce o bu durumun çözümüne nasıl katkıda bulunabilir?

Tablo 6. Beşinci probleme yönelik cevaplanma dağılımı

\begin{tabular}{lcccccc}
\hline & Kız & $\%$ & Erkek & $\%$ & $\begin{array}{c}\text { Toplam } \\
\text { (f) }\end{array}$ & $\begin{array}{c}\text { Toplam } \\
\%\end{array}$ \\
\hline Doğru cevap veren kişi sayısı & 4 & 5.63 & 3 & 4.35 & 7 & 5 \\
Kısmen doğru cevap veren & 36 & 50.70 & 36 & 52.17 & 72 & 51.43 \\
Cevaplamayan kişi sayısı & 31 & 43.66 & 30 & 43.48 & 61 & 43.57 \\
\hline
\end{tabular}

Tablo 6'yı incelediğimizde, dördüncü soruya 4'ü kız öğrenci ve 3'ü erkek öğrenci olmak üzere toplam 7 (\%5) öğrencinin doğru cevap verdiği, 72 (\%51.43) öğrencinin ise kısmen cevap verdiği, 61 (\%43.57) öğrencinin problemi cevaplayamadığı görülmektedir. 


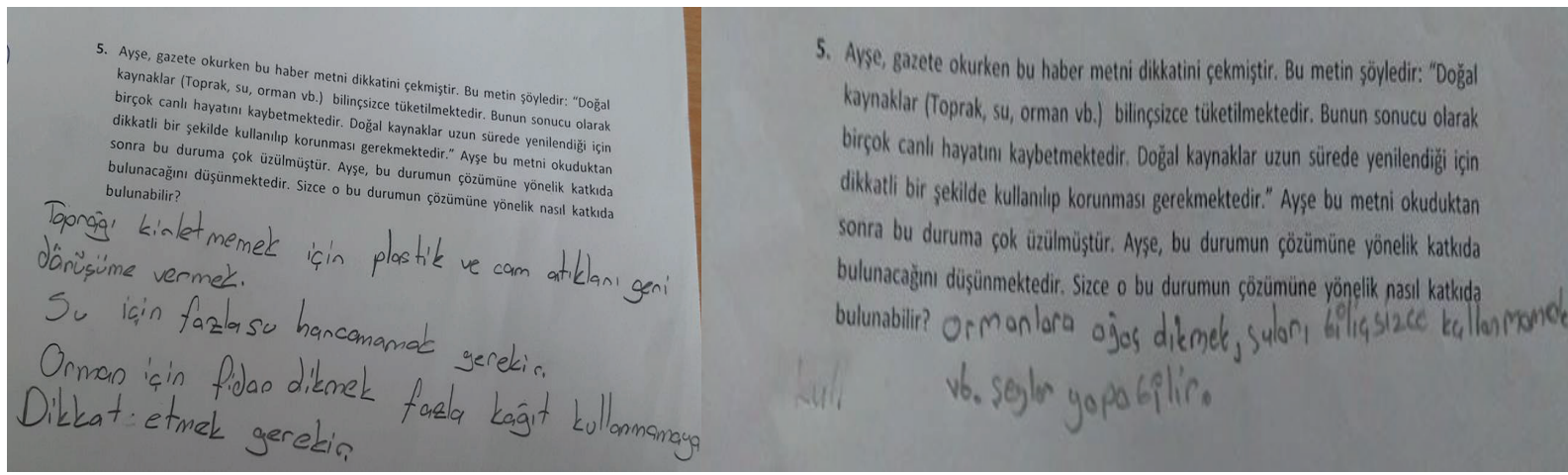

Şekil 8. Öğrencilere ait sırasıyla doğru ve kısmen doğru cevaplar

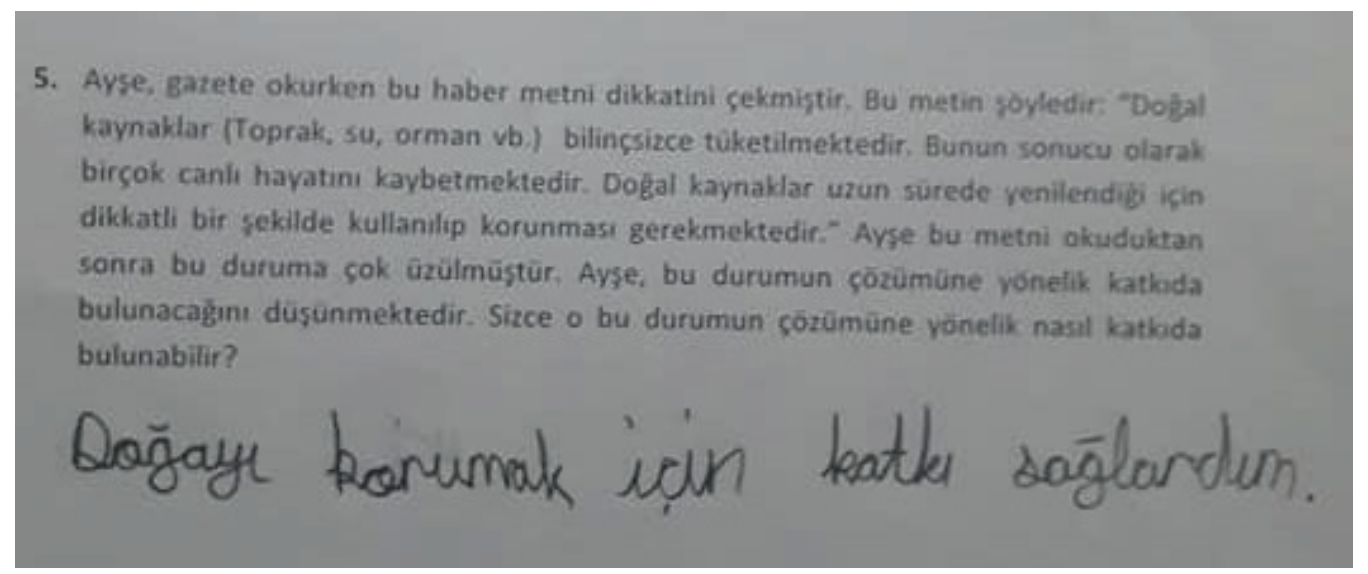

\section{Şekil 9. Öğrenciye ait yanlış cevap}

Genel olarak öğrencilerinden gelen yazılı açıklamalarda Ö2 (1. soru), Ö20 (1, 2, 3. soruları) Ö23 (4 ve 5. soruları), Ö80 (1. soru), Ö88 (2. soru), Ö140 (4. soru) kodlu öğrenciler soruyu "anlamadıklarını" belirtirken; Ö9 (3. soru), Ö27 (1. soru), Ö40 (4. soru), Ö135 (2. soru) kodlu öğrenciler ise, "bilmiyorum, bulamadım, anlamadım, yapamıyorum, çok zorıandım" ifadelerini kullanmışlardır. Diğer birçok öğrenci ise problem anladıklarını fakat ne yapacaklarını bilmediklerini belirtmişlerdir. Öğrencilerin vermiş olduğu yazılı açıklama kâğıtlarının tamamında defalarca yazıp silme şeklinde oluşmuş olan kalem izlerinden öğrencilerin problemleri çözmek için yoğun çaba sarf ettikleri görülmüştür. Bu çabalar bazen problemin çözülmesiyle sonuçlanırken, bazen de şekil 10'daki gibi silinmiş kalem izleriyle sonuçlanmıştır. Öğrenciler yukarıdaki ifadeler dışında herhangi bir çözememe nedeni ileri sürmemişlerdir.

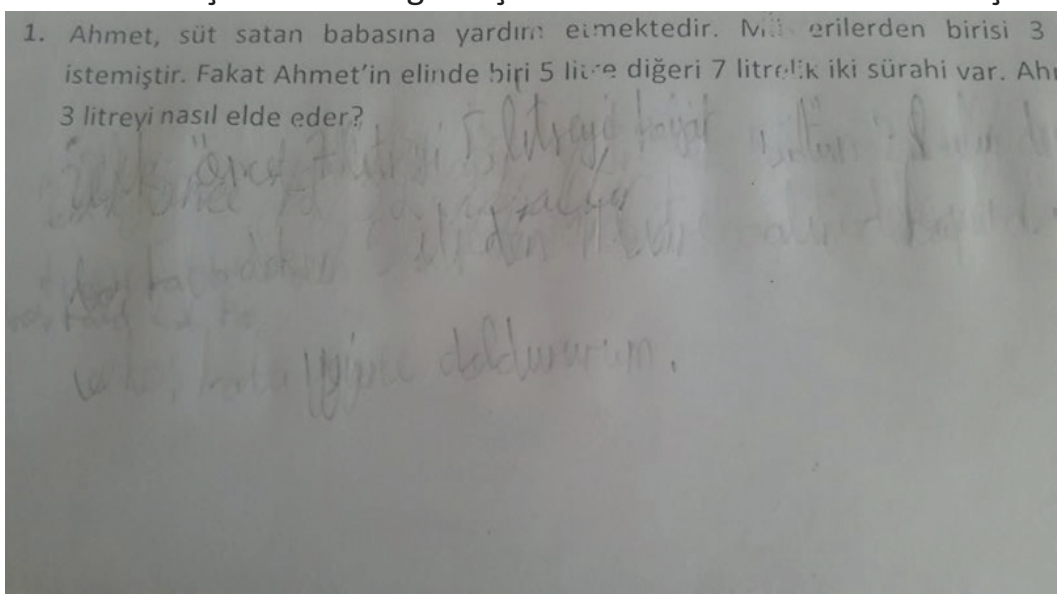

\section{Şekil 10. Ö49 nolu öğrencinin cevabı}

Araştırmanın ikinci sorusu, "Cinsiyete göre problem çözme düzeyleri arasındaki farklıık nasıldır?” sorusudur. Tablo 7'yi incelendiğinde soruların tamamına verilen cevaplar üzerinden, cevap veren kız ve erkek öğrenci toplam sayısı şöyledir; doğru cevap veren kız öğrenci sayısı toplamı 42 (\%11.8), doğru cevap veren erkek öğrenci sayısı 31 (\%9), kısmen 
doğru cevap veren kız öğrenci sayısı toplamı 105 (29.6), kısmen doğru cevap veren erkek öğrenci sayısı toplamı 102 (\%29.6), cevaplamayan kız öğrenci sayısı toplamı 208 (\%58.6), cevaplamayan erkek öğrenci sayısı toplamı ise 212'dir (\%61.4). Kız ve erkek öğrencilerden elde edilen veriler arasında anlamlı bir farklılık olup olmadığını belirlemek amacıyla yapılan kay kare test sonucunun, anlamlılık düzeyi değeri $(P=.000) .05$ 'ten küçük çıkmıştır. Bu test sonucuna göre çaıışmaya katılan gurup için; kız ve erkek öğrencilerin problem çözme düzeyleri karşılaştırıldığında kız öğrenciler lehine anlamlı bir farklılaşmanın olduğu gözlenmektedir.

Tablo 7. Soruların hepsine öğrencilerin verdiği yanıtların toplanmasıyla elde edilen verilerin yüzde ve frekans dağılımı

\begin{tabular}{|c|c|c|c|c|c|c|}
\hline & \multicolumn{2}{|c|}{ Kız } & \multicolumn{2}{|c|}{ Erkek } & \multicolumn{2}{|c|}{ Toplam Öğrenci Yanıtı } \\
\hline & f & $\%$ & f & $\%$ & Frekans Toplmı & $\begin{array}{c}\text { Frekans Toplamı } \\
\text { Yüzdesi }\end{array}$ \\
\hline Doğru cevap toplamı & 42 & 11.8 & 31 & 9 & 73 & 10.4 \\
\hline Kısmen doğru cevap toplamı & 105 & 29.6 & 102 & 29.6 & 207 & 29.6 \\
\hline Cevaplanmayanların toplama & 208 & 58.6 & 212 & 61.4 & 420 & 60 \\
\hline$\chi^{2}: 511.397$ & & df: 4 & & & $p: .000(p<.05)$ & \\
\hline
\end{tabular}

\section{Sonuç ve Tartışma}

Bu çalışmada, "Maddeyi tanıyalım" ünitesi kapsamında hazırlanmış olan 5 adet rutin olmayan problemin öğrencilere uygulanıp, öğrencilerin çözüme yönelik yazılı açıklamaları alınmış ve öğrencilerin problem çözme düzeyleri ve cinsiyete göre problem çözme becerileri arasındaki farklılıklar incelenmiştir. Birinci araştrrma sorumuz, "4. sınıf öğrencilerinin fen bilimleri dersinin maddeyi tanıyalım ünitesi kapsamında hazırlanan rutin olmayan problemleri çözme becerisi hangi düzeydedir?", sorusudur. Bu soruya yönelik tablo 7 incelediğinde; sorulara verilen yanıtların \% 10.4'ünün doğru, \%29.6'sının kısmen doğru olduğu; \%60 oranında ise soruların cevaplanamadığı görülmektedir. Bu bulgudan hareketle rutin olmayan (günlük yaşam) problemleri çözme becerisinin, istenilen düzeyde olmadığı belirtilebilir. Ulaşılan bu bulgu, Bayazıt (2013), Gökkurt, Örnek, Hayat ve Soylu (2015), Karataş ve Güven (2010), Kaya ve Kablan (2018), Koç (2014), Phonapichat, Wongwanich \& Sujiva (2014), Saygılı'nın (2017) araştırma bulgularından sağlanan “öğrencilerin problem çözme becerileri beklenilen seviyede değildir." şeklinde ifade edilebilecek bulgularla örtüşmektedir. Nitekim Bayazıt'ın (2013) bulguları; öğrencilerin gerçek dünya problemleri olarak da adlandırılabilecek rutin olmayan problemlere cevap verirken; problem durumuna uygunluğu gözetmeksizin çözüm önerileri ileri sürdüklerini ortaya koymaktadır. Öğrenciler, okul bilgisi olarak değerlendirilebilecek alternatif yaklaşımları, uygun stratejileri ve matematiksel modelleri hayata uyarlamakta zorlanmaktadırlar. İlgili çalışamada öğrencilerin gerçek yaşam problemleri karşısında kritik bir akıl yürütme sergileyememeleri ve sadece problemin kavramsal çerçevesinin çağrıştırdıklarıyla yetinmeleri çalışmamızla uyum içinde olan ilginç bir bulgudur (Bayazıt, 2013). Gökkurt ve arkadaşlarının (2015), çalışma bulgularına göre; öğrencilerin problemi anlama ve değerlendirme ile problem kurma aşamalarında oldukça düşük bir başarı sergiledikleri belirlenmiştir. Buna göre öğrenciler daha önceden aşina oldukları problem durumlarında işlemsel bilgiyi etkin bir şekilde kullanırken; problemin içeriğine yönelik sorularda yetersiz kalmış ve problemi tanımlayamamışlardır. Bu bulgu, çalışmamızın katılımcılarının rutin olmayan problem durumlarında veya gerçek yaşam problemlerinde beklenen düzeyi gösterememeleriyle uyumlu bir bulgudur. Kaya ve Kablan'ın (2018), "Rutin Olamayan Problemlerle Ilgili Yapılan Araştirmaların Analizi" başlıklı makalesi de, çalışmamızın bulgularıyla oldukça özgün bir biçimde uyum göstermektedir. Buna göre, öğrencilerin rutin olmayan problemlere çözüm önerileri sunmakta yetersiz kaldıkları; çoklu stratejilere başvuramadıkları; genellikle aşina olunan rutin problemlerde kullandıkları yöntemleri kullanmakta ısrarcı oldukları belirlenmiştir. Phonapichat ve arkadaşları (2014), öğrencilerin okuma, okuduğunu anlama becerileriyle matematik başarısı arasında önemli bir ilişki olduğunu ileri sürmektedirler. Rutin olmayan problem durumlarının okuma becerisini etkin bir biçimde kullanmayı gerektiren yeni durumlar olduğu düşünüldüğünde; çalışmamız bulgularının bu çalışma bulgularıyla uyumlu olma nedeni anlaşılabilmektedir. İ gili çalışmada öğrencilerin metinsel problem durumlarını matematiksel ifadelere dönüştüremedikleri de belirtilmektedir. Bu yöndeki bulgu, rutin olmayan-gerçek yaşam problemlerinin metinsel yapılarının öğrenciler tarafindan iyi okunup değerlendirilememesi ve dolayısıyla matematiksel olarak formüle edilememesinin; öğrencilerin matematik başarısını olumsuz yönde etkilemiş olabileceği yorumunu yapmamıza imkan vermektedir. Lamb'in (2010) ve Jiban \& Dino'nun (2007) yaptıkları çalışmalarda öğrencilerin matematik başarılarında okuma ve okuduğunu anlama becerisinin önemli bir belirteç (indikatör) olduğunu ifade etmeleri bu yöndeki yorumu

| Kastamonu Eğitim Dergisi, 27(5), 2019| 
güçlendirir niteliktedir.

Ülkemizin, 2003 yılından itibaren dahil olduğu 3 yıl arayla yapılan uluslararası öğrenci değerlendirme programı (PISA), 15 yaş grubu öğrencilerin okulda edindikleri fen, matematik ve okuma becerilerini günlük yaşamda kullanabilme yeterliliklerini değerlendirmektedir. Bu değerlendirmeyi yaparken, okuryazarlık kavramı vurgulanmaktadır. Okuryazarlık kavramının; öğrencilerin karşılaşttkları problemleri çözme, bilgi ve becerilerini günlük hayatta kullanabilme, mantıksal çıkarımlar yapma, analiz etme, etkili iletişim kurma yeterliklerini içerdiği ifade edilmektedir. Bu kapsamda ülkemizde 2006-2015 yılları arasında Ekonomik İşbirliği ve Kalkınma Teşkilatı (OECD) tarafindan uluslararası öğrenci değerlendirme programı (PISA) kapsamında yapılan raporlamalarda Türkiye'de fen okuryazarlık puanlarının sürekli olarak değerlendirmeye katılan bütün ülkelerin genel ortalamasının altında kalması; ilgili yaş grubunda, problem çözme becerisilerinin yeterince geliştirilemediğinin verisi olarak gösterilebilir (MEB, 2015).

Alan yazında problem çözme ile ilgili yapılan araştırmalarda, problem çözme becerilerinin öğretimle geliştirilebileceğini vurgulanmışttr (Hsiao, Lin, Chen \& Peng, 2018; Ilgın veArslan, 2012; Kaya ve Kablan, 2018; Petersen, McAuliffe \& Vermeulen, 2017; Ulu, Tertemiz ve Peker, 2016; Uyar ve Bal, 2015; Wismath, Orr \& Zhong, 2014). Öğrencilerde problem çözme becerisilerinin istenilen düzeyde olmamasında; öğretmenlerin problem çözmede yetersiz kalması (Mwei, 2017), ülkemizde uygulanan çoktan seçmeli sınav sistemi (Marchiş, 2013), öğrencinin problemi anlayamaması ve o problemi çözmeye yönelik motivasyonda olamayışı, öğretmenlerin problemi öğrenciye ilgi çekici bir şekilde, açık ve anlaşılır olarak anlatamaması, problemin öğrenci seviyelerine uygun olmaması, derslerde çok zor ya da çok kolay problemlere yer verilmesi şeklindeki açıklamaların birer neden olabileceği belirtilebilir (Bingham, 2004; Filiz ve Abay, 2017; Poyla, 1997). Bununla birlikte, öğrencilerde var olan özgüven eksikliğinin de, problem çözme davranışından kaçınmaya neden olabileceği ifade edilebilir (Mafakheri, Rostamy, Shahvarani \& Behzadi, 2013). Çalışmamızdan sağlanan bulgular ve diğer alanyazın bulgularına göndermede bulunarak; öğretmenlere, problem çözme becerilerinin öneminin kavratılmasının ve öğrencilerde bu yöndeki becerilerin nasıl geliştirileceğine yönelik eğitim verilmesinin, öğretim programlarında ve derslerde rutin olmayan problem durumlarına daha çok yer verilmesinin gerekli olduğu ileri sürülebilir (Gür ve Hangül, 2015; Yılmaz, 2019).

Çalışmamızda, öğrencilerin cevap kağıtları incelendiğinde; birçok öğrencinin problemleri çözmek için yoğun bir çaba içine girdiği görülmüştür. Bu çaba öğrencilerin problem çözmeye karşı istekli olduklarının bir kanıt olarak gösterilebilir. Ayrıca problemlerin birçok farklı çözüm yolu olmasına rağmen, problemleri çözen öğrenciler ile problemleri kısmen çözen öğrencilerin izledikleri çözüm yolu (sistematik liste yapma, diyagram çizme) birbirine benzemektedir. Ulaşılan bu bulgu, derslerde daha çok rutin problemlerin çözdürüldüğüne ve böylece öğrencilerin problemlerin sadece tek bir çözüm yolunun olduğu anlayışını geliştirmiş olabileceklerine bir gönderme yapabilir (Incebacak ve Ersoy, 2018; Kaya, Kablan \& Rice, 2014). Ayrıca Yılmaz'ın (2019), araştırma sonuçlarından biri olan, öğrencilerin rutin problemleri çözme sürecinde tek çözüm yolu kullanma oranlarnın \%90 seviyelerini bulması ve öğrencilerden bu çözüm önerisinin dışında ikinci çözüm önerisi istendiğinde başarı oranının \%36'ya düşmesi, öğrencilerin bir problemin çözümünde sadece bir yol olduğu anlayışına sahip oldukları yönündeki düşünceyi destekler niteliktedir.

Araştırmanın ikinci sorusu, "cinsiyete göre problem çözme düzeyleri arasındaki farklıık nasıldır?” sorusudur. Buna göre Tablo 7 incelediğinde, yapılan kay kare testi sonucu kız öğrencilerin lehine anlamlı bir farklılık olduğu gözlenmektedir. Alanyazında, problem çözme becerisine yönelik yapılan araştırmalarda farklı bulgulara ulaşılmış olduğu belirlenebilir. Ajai ve Imoko (2015), Bahçeci ve Kinay (2013), Çevik ve Özmaden (2013), Genç ve Kalafat (2010) ve Koç'un (2014), yapmış oldukları araştırma bulgularında, problem çözme becerileri ile cinsiyet arasında anlamlı bir farkın olmadığını belirlenirken; Polat ve Tümkaya (2010), Şahin, íbili ve Uluyol (2016) ve Sezen ve Paliç (2011); yapmış oldukları araştrrmalarda, kız öğrenciler lehine anlamlı bir farkın bulunduğunu belirlemişlerdir. Ayrıca Ekonomik İşbirliği ve Kalkınma Teşkilat (OECD) tarafindan 2015 yılında uluslararası öğrenci değerlendirme programı (PISA) kapsamında yapılan araştırmada, Türkiye'de kız öğrencilerin fen okuryazarlık (problem çözme becerisi, okulda öğrenilen bilgi ve becerileri günlük hayatta kullanma vb...) ortalama puanı, erkek öğrencilerin fen okuryazarlık ortalama puanından yüksek çıkmıştır (MEB, 2015). Zhu (2007) ise, yürütmüş olduğu araştırma bulgusunda, erkek öğrenciler lehine anlamlı bir farkın bulunduğunu belirtmiştir. Bazı araştırmalarda kız öğrenciler lehine çıkan farklııkların nedenlerinden biri olarak, kız öğrencilerin erkek öğrencilere oranla problem çözmeye yönelik daha olumlu bir algı içinde bulunması gösterilebilir (Sezen ve Paliç, 2011). Sezen ve Paliç̧in (2011) ilgili bulgusundan hareketle, kız öğrencilerin problem çözme konusunda erkek öğrencilere oranla daha ısrarcı davrandığı ve böylece daha yetkin hale geldiği iddia edilebilir.

\section{5. Öneriler}

Araştırma bulguları genel olarak incelendiğinde, öğrencilerin öğrendikleri bilgileri günlük yaşama transfer etmede zorluk yaşadıkları ve problem çözme becerisinin cinsiyet değişkeni bakımından anlamlı bir fark yarattı̆ı izlenmektedir. 
Bu genel bulgu fadesine dayanılarak; öğretmenlere, öğrencilerin problem çözme becerilerini geliştirme konusunda yeterliklerini arttırıcı eğitim verilmesi gerekliliği öneri olarak getirilebilir. Aynı zamanda yeni programlara göre hazırlanacak yeni ders kaynaklarında, günlük hayata yönelik problem çözme etkinliklerinin sayısı da arttrılabilir. Bununla birlikte sınavlarda günlük yaşam problemlerine daha fazla yer verilebilir.

\section{Kaynakça}

Açıkgöz, K. Ü. (2014). Aktif öğrenme. İzmir: Biliş Yayınevi.

Ajai, J.T. \& Imoko, I.I. (2015). Gender differences in mathematics achievement and retention scores: A case of problem-based learning method. International Journal of Research in Education and Science (IJRES), 1 (1), $45-50$.

Altun, M. (2008). Matematik öğretimi. Bursa: Aktüel Akademi Yayınları.

Aykaç, N. (2005). Öğrenme ve öğretim sürecinde aktif öğrenme yöntemleri. Ankara: Naturel Yayıncılık.

Bayazıt, i. (2013). ilköğretim 7. ve 8. sınıf öğrencilerinin gerçek-yaşam problemlerini çözerken sergiledikleri yaklaşımlar ve kullandıkları strateji ve modellerin incelenmesi. Kuram ve Uygulamada Eğitim Bilimleri, 13 (3), 1920 - 1927

Baydar, M. L., Gül, H. ve Akçil, A. (2007). Bilimsel araştırmanın temel ilkeleri. Isparta: Süleyman Demirel Üniversitesi Basımevi.

Bağçeci, B. ve Kinay, i. (2013). Öğretmenlerin problem çözme becerilerinin bazı değişkenlere göre incelenmesi. Elektronik Sosyal Bilimler Dergisi, 12 (44), 335-347.

Bingham, A. (2004). Çocuklarda problem çözme yeteneklerinin geliştirilmesi (Çev: Ferhat OĞUZKAN). Ankara: Milli Eğitim Bakanlığı Yayınları.

Boonen, A. J. H, Reed, H., C., Schoonenboom J. \& Jolles J. (2016). It's not a math lesson - we're learning to draw! Teachers' use of visual representations in instructing word problem solving in sixth grade of elementary school. Frontline Learning Research, 4 (5), $34-61$.

Büyüköztürk, Ş. (2016). Veri Analiz El Kitabı. Ankara: Pegem Akademi.

Büyüköztürk, Ş., Çakmak, E. K., Akgün, Ö. E., Karadeniz, Ş. ve Demirel, F. (2016). Bilimsel araştrrma yöntemleri. Ankara: Pegem Akademi Yayıncilık.

Csapó, B. \& Funke, J. (2017). The nature of problem solving: Using research to Inspire 21st century learning. OECD Publishing, Paris. Erişim adresi: http://dx.doi.org/10.1787/9789264273955-en

Celebioğlu, B., Yazgan, Y. ve Ezentaş, R. (2010). Usage of non-routine problem solving strategies at first grade level. Procedia Social and Behavioral Sciences, 2 (2010) 2968-2974.

Çevik, B., D. ve Özmaden, B. (2013). Öğretmen adaylarının problem çözme becerileri. Eğitim ve Öğretim Araştırmaları Dergisi, 2 (3), 270-275.

Çepni, S. (2010). Araştırma ve proje çalışmalarına giriş. Trabzon: Yazarın Kendisi.

Çepni, S. (Ed.). (2014). Fen ve teknoloji öğretimi. Ankara: Pegem Akademi.

Doğanay, A. (Ed.). (2012). Öğretim ilke yöntem ve teknikleri. Ankara: Pegem Akademi Yayınları.

Dostál J. (2015). Theory of problem solving. Procedia - Social and Behavioral Sciences, 174, 2798- 2805.

Filiz, S., B. ve Abay, S. (2017). Sınıf öğretmeni adaylarının rutin olmayan problemlerdeki problemi anlama durumları. Eğitim Kuram ve Uygulama Araştrrmaları Dergisi, 3 (3), 97-118.

Genç, S. Z. ve Kalafat, T. (2010). Öğretmen adaylarının empatik becerileri ile problem çözme becerileri. Kuramsal Eğitim Bilim, 3 (2), 135-147.

Gökkurt, B., Örnek, T., Hayat, F.\& Soylu, Y. (2015). Öğrencilerin problem çözme ve problem kurma becerilerinin değerlendirilmesi. Bartın Üniversitesi Eğitim Fakültesi Dergisi, 4 (2), 751-774.

Gür,H. ve Hangül, T. (2015). Ortaokul öğrencilerinin problem çözme stratejileri üzerine bir çalışma .Pegem Eğitim ve Öğretim Dergisi, 5 (1), 2015, 95-112.

Hsiao H., S. , Lin C., Y., , Chen J.,C., \& Peng Y., F. (2018). The influence of a mathematics problem-solving training system on first-year middle school students. EURASIA Journal of Mathematics, Science and Technology Education, 14 (1), 77-93.

Inoue, N. (2005). The realistic reasons behind unrealistic solutions: The role of interpretive activity in word problem solving. Learning and Instruction, 15, 69-83.

Ilgın, H. ve Arslan, D. (2012). Türkçe dersinde metinlerle problem çözme öğretiminin öğrencilerin problem çözme becerilerine etkisi. Ahi Evran Üniversitesi Kırşehir Eğitim Fakültesi Dergisi, 13 (2), 157-176.

Işık, C. ve Kar, T. (2011). illköğretim 6, 7 ve 8. sınıf öğrencilerinin sayı algılama ve rutin olmayan problem çözme becerilerinin incelenmesi. Ahi Evran Üniversitesi Eğitim Fakültesi Dergisi, 12 (1) , 57-72.

Incebacak, B., B. ve Ersoy, E. (2018). Ortaokul Öğrencilerinin Yaratıı Problem Çözme Becerileri. Necatibey Eğitim Fakültesi Elektronik Fen ve Matematik Eğitimi Dergisi, 12 (1), 1-24.

Jiban, C. L., \& Deno, S. L. (2007). Using math and reading curriculum-based measurements to predicts state mathematics test performance: Are simple one-minute measures technically adequate?. Assessment of Effective Intervention, 32(2), 78-89.

| Kastamonu Eğitim Dergisi, 27(5), 2019| 
Karataş, İ. ve Güven, B. (2010). Ortaöğretim öğrencilerinin günlük yaşam problemlerini çözebilme becerilerinin belirlenmesi. Erzincan Eğitim Fakültesi Dergisi, 12 (1), 201-2017.

Karasar, N. (1994). Bilimsel Araştırma Yöntemi. Ankara: Araştırma Eğitim Danışmanlık Ltd.

Kaya, S., Kablan, Z., \& Rice, D. (2014). Examining question type and the timing of IRE pattern in elementary science classrooms. Journal of Human Sciences, 11(1), 621-641.

Kaya, S. ve Kablan, Z. (2018). Rutin Olmayan Problemlerle İlgili Yapılan Araştırmaların Analizi. Necatibey Eğitim Fakültesi Elektronik Fen ve Matematik Eğitimi Dergisi, 12 (1), 25-44.

Koç, C. (2014). İlköğretim öğrencilerinin problem çözme becerilerine yönelik algıları ve öğrenme sürecinde yardım istemeleri. Kastamonu Eğitim Dergisi, 23 (2), 659-678.

Lamb, J. H. (2010). Reading gread levels and mathematics assessment: an analysis of Texas mathematics assessment items and their reading difficulty. The mathematics Educator, 20(1), 22-34.

Marchiş, I. (2013). Primary school pupıls' problem solving competency and reasoning skills. Pedacta, 3 (1), 25-32.

Mwei, P., K. (2017). Problem solving: how do in-service secondary school teachers of mathematics make sense of a non-routine problem context? International Journal of Research in Education and Science, 3 (1), 31-41.

Mataka, L.M., Cobern, W.W., Grunert, M., Mutambuki J., \& Akom, G. (2014). The effect of using an explicit general problem solving teaching approach on elementary preservice teachers' ability to solve heat transfer problems. International Journal of Education in Mathematics, Science and Technology, 2 (3), 164-174.

MEB(2015).2015 PISA ulusal raporu. Erişim adresi: http://pisa.meb.gov.tr/wp content/uploads/2014/11/PISA2015_UlusalRapor.pdf

MEB (2017). Illköğretim kurumları fen bilimleri dersi öğretim programı. Ankara: MEB Yayınları.

MEB (2018). ilköğretim kurumları fen bilimleri dersi öğretim programı. Ankara: MEB Yayınları.

Mafakheri, S., Rostamy M., M, Shahvarani, A., Behzadi, M., H. (2013). The study of effect of the main factors on problem solving self-confidence using cooperative learning. Mathematics Education Trends and Research, 1-7.

Nasriah, L. (2017). Problem solving methods to improve understanding of learning social subject matter for students of vII of smp negerii 2 tigaraksa, Indonesia. European Journal of Education Studies, 3 (4), 216-222.

Phonapichat, P., Wongwanich S. \& Sujiva, S. (2014). An analysis of elementary school students' difficulties in mathematical problem solving. Procedia - Social and Behavioral Sciences, 116, $3169-3174$.

Petersen, B., McAuliffe, S. \& Vermeulen, C.. (2017). Writing and mathematical problem solving in Grade 3', South African Journal of Childhood Education, 7 (1), 2223-7674.

Polat, H. R. ve Tümkaya, S. (2010). Sınıf öğretmenliği öğrencilerinin düşünme ihtiyacına göre problem çözme becerilerinin incelenmesi. Ilköğretim Online, 9 (1), 346-360.

Polya, G. (1997). Nasıl çözmeli ? (Çev. Feryal Halatçı). İstanbul: Sistem Yayıncılık.

Rohmah M. \& Sutiarso S. (2018). Analysis problem solving in mathematical using theory newman. EURASIA Journal of Mathematics, Science and Technology Education, 14 (2), 671-681.

Saracaloğlu, A., S., Serin, O. ve Bozkurt, N. (2001). Dokuz Eylül Üniversitesi Eğitim Bilimleri Enstitüsü Öğrencilerinin Problem Çözme Becerileri ile Başarıları Arasındaki ilişki. M.Ü. Atatürk Eğitim Fakültesi Eğitim Bilimleri Dergisi, 14, 121-134.

Saygılı, S. (2017). Examining the problem solving skills and the strategies used by high school students in solving non-routine problems ,E-International Journal of Educational Research, 8 (2), 91-114.

Sezen, G. ve Paliç, G. (2011). Lise öğrencilerin problem çözme becerisi algılarının belirlenmesi. 2 nd International Conference on New Trends in Education and Their Implications, 27-29 April, Antalya-Turkey.

Şahin, S., İbili, E. ve Uluyol, Ç. (2016). Öğretmen adaylarında problem çözme eğilimi ve internet bağımlılığı ilişkisinin incelenmesi. Afyon Kocatepe Üniversitesi Sosyal Bilimler Dergisi, 19, (1), 1-21.

Ulu, M., Tertemiz, N. ve Peker, M. (2016). Okuduğunu anlama ve problem çözme stratejileri eğitiminin ilköğretim 5. sınıf öğrencilerinin rutin olmayan problem çözme başarısına etkisi. Afyon Kocatepe Üniversitesi Sosyal Bilimler Dergisi, 18 (2), $303-340$.

Uyar, G. ve Bal, A.P. (2015). Altıncı sınıf öğrencilerinde probleme dayalı̈ öğrenmenin akademik başarıya etkisi. Pegem Eğitim ve Öğretim Dergisi, 5 (4), 361-374.

Van Garderen, D., \& Montague, M. (2003). Visual-spatial representation, mathematical problem solving, and students of varying abilities. Learning Disabilities Research \& Practice, 18, 246-254. doi: http://dx.doi.org/10.1111/1540-5826.00079

Yılmaz, R. (2019). Sınıf öğretmeni adaylarının problem çözme sürecinde kullandıkları stratejiler: rutin problem çözme durumları. Kastamonu Education Journal, 27(1), 85-94.

Wismath S., Orr, D., \& Zhong M. (2014). Student perception of problem solving skills. Transformative Dialogues: Teaching \& Learning Journal 7 (3), 1-17.

Zhu, Z. (2007). Gender differences in mathematical problem solving patterns: A review of literature. International Education Journal, 8 (2), 187-203. 